\title{
Socialismo mulato: Soviet Fascination with Race in Cuba
}

\author{
Damaris Puñales-Alpízar
}

\begin{abstract}
In the Soviet imaginary, the Cuban mulato represented not only an exotic other but also the realization of another kind of socialism, possible in other conditions and at other coordinates, (almost) far from Soviet reach. In general terms, Cubans came to fulfill a multilevel imaginary aspiration of Soviet identity related to Black and exploited people, Latin America, the United States, and the dissemination of the socialist ideology around the world. The Soviet fascination with, commitment to, and admiration for people of color was reinforced in this case by the added bonus that Cubans were comrades from a socialist island just a few miles from the US coast. At the geopolitical level, that fascination translated into the election of the first Black man to be sent into the cosmos; at an aesthetic level, it is related to a specific kind of poetry produced by Soviet authors in which the emphasis was on Cubans as mulatos, as this article will demonstrate through the analysis of literary works by authors such as Mayakovski, Yevtushenko, Kovaliov, Smolnikov, and Gamzatov. The third aspect of this fascination was made manifest in the many interracial marriages between Soviet women and Black Cuban men.
\end{abstract}

Keywords: race, socialist ideology, mulata Cuba, Black Cuban in the space.

\section{THE FIRST BLACK IN THE COSMOS}

The name José Armando López Falcón is nearly unknown to any Cuban today. It resonates in the memory of only a few people on the island. López Falcón was a Cuban cosmonaut, though he never actually went into space and his fame has been thoroughly eclipsed by his peers. If you ask Cubans of any generation about Arnaldo Tamayo Méndez, by contrast, most will recognize the name and his history. López Falcón and Tamayo Méndez were the two Cubans chosen to be part of Interkosmos, the Eastern bloc's early space program run by the former Soviet Union. Before Tamayo flew into the cosmos in 1980, they trained for two years. It was not until a couple of days before the launch of the space rocket that they learned which of them was going to leave Earth. (i)

When in September 1980 Arnaldo Tamayo Méndez took off as part of the Soyuz 38 mission from the Baikonur Cosmodrome, in what was then the Soviet Republic of Kazakhstan, on a journey that would last almost eight days, he not only became the first Cuban and Latin American to go out into interstellar space but was also the first person of African descent to become a cosmonaut. His name became part of History (yes, with a capital $\mathrm{H}$ ), and he attained hero status both in Cuba and in the Socialist bloc (ii).

It was the Cold War era, and space was one of the rival countries' most important battlefields. Years earlier, the Soviet Union had decided to make its space program egalitarian and inclusive: in addition to sending the first man into space, the Soviets also sent the first woman (Valentina Tereshkova, in 1963) and the first Asian (Pham Tuan, in 1980). Besides its scientific scope, the program also had a robust geopolitical agenda. For instance, the first cosmonaut from a country other than the Soviet Union and the United States was the Czechoslovak pilot Vladimir Remek, son of a Czech mother and a Slovak father. His 1978 mission coincided with the thirtieth anniversary of the Soviet-backed Czechoslovak coup d'état in 1948 and the tenth anniversary of the Soviet invasion of Czechoslovakia in 1968 by Warsaw Pact troops. (iii)

Following the logic of this representativeness principle and geopolitical agenda maintained by the Soviets, we can speculate that Arnaldo Tamayo Méndez filled a quota by 
being the first Afro-descendant cosmonaut in the space race. And one cannot help wondering, all these years later, what real impact his race had on the decision to choose him rather than José Armando López Falcón to be the Cuban representative who would accompany Yuri Romanenko.

Of course, for Cuba it was also important that its first man in space - the only one so far-be Black. This action promoted the government's agenda for racial equality undertaken since the beginning of the Revolution, especially at the level of political and propagandistic discourse. (iv)

This speculative exercise in approaching this topic does not in any way imply a desire to dismiss Tamayo Méndez's talents, abilities, and preparation to become a cosmonaut. It is merely a hypothesis about the geopolitical and ideological reasons that both the Soviet Union and Cuba had to choose him for the mission.

Tamayo and Romanenko became the faces on the posters and received all the media attention. Tamayo met all the requirements to become the program's and Cuba's "poster man": born into a poor Black family, as a child he had to work as a shoeshine boy, a job that was "eradicated" after the Cuban Revolution of 1959. In the late 1950s, he joined the Association of Young Rebels, the urban arm of the rebel army in the mountains. After the Revolution, he first studied in the Soviet Union to become an aviation technician and then trained to be a pilot.

After months of training as part of the Interkosmos program, which had begun in 1978, the two Cuban cosmonauts were paired with their Soviet counterparts. Tamayo Méndez joined Colonel Yuri Romanenko, who had previously flown on the Soyuz 26 mission to the Salyut 6 space station in December 1977; the mission had lasted ninety-six days and included a spacewalk of about ninety-minute by Romanenko. López Falcón was matched up with Colonel Yevgeny Jrunov, a research engineer who had flown on the Soyuz 5 to dock it with the Soyuz 4 in January 1969; he had also conducted a spacewalk.

According to Dumitru-Dorin Prunariu, the Romanian candidate who trained alongside Tamayo Méndez and López Falcón in the Interkosmos program, political factors influenced the selection of the cosmonaut who would fly:

Both candidates were very well trained, very well prepared, but Tamayo was the first Black person to be sent into space. That was a political challenge for Russia... for the Soviet Union in that time, to send him. He was well prepared, no doubt, but his Russian was pretty poor, compared to the other one [José Armando López Falcón]. (Burgess and Vis 134)

Romanenko said of Tamayo Méndez, "He is a very determined individual, but also very kind and has a sharp sense of humor. Of course, as a real Cuban, he is temperamental but is in good command of his emotions" (Burgess and Vis
134). What Romanenko meant with this description - "a real Cuban" and "temperamental" - is unknown, but it seems to contrast with what Yevgeny Jrunov said about his partner, José Armando López Falcón:

Me gusta la capacidad de José Armando de demostrar sangre fría en la más complicada situación. Durante las clases ... ni se dio un caso en que él perdiera su dominio. Es más, reiteradamente observé: cuánto más se "caldea" a veces la situación, con tanta más tranquilidad actúa José Armando. Es su rasgo más valioso. ("Vuelo conjunto URSS-Cuba" 47)

The speech delivered by Fidel Castro on October 15, 1980, in the Palace of Conventions in Havana, to welcome and celebrate the return of the men that participated in the first Soviet-Cuban space flight, also offers some clues about his possible influence on the final cosmonaut selection. The Cuban leader said:

Con la Revolución las puertas se abrieron para él [referring to Tamayo Méndez] al igual que para toda nuestra juventud, al igual que para todo nuestro pueblo: la oportunidad de estudiar, la oportunidad de superarse, la oportunidad de servir a su pueblo.

Era una opción suya, como joven humilde, y se ha dicho y se ha repetido y se ha insistido, en su cuna humilde. Y es porque realmente constituye todo un símbolo el hecho de que nuestro primer cosmonauta, y el primer cosmonauta de América Latina y el primer cosmonauta de África, y no es un capricho que nosotros digamos que es también el primer cosmonauta de África, porque Tamayo, hombre eminentemente negro, que lleva también en su sangre la sangre del indio y la sangre española, es todo un símbolo de la sangre mezclada que en el crisol de la historia de nuestra patria dieron origen a nuestro pueblo; sangre africana, sangre india, sangre española. Por eso decimos que también simboliza a África, puesto que es el primer descendiente de africanos que ha viajado al espacio. Y es todo un símbolo que un hombre de origen tan humilde haya alcanzado tan extraordinario éxito, porque, desde luego, solo la Revolución y únicamente la Revolución, habría hecho posible que un joven como Tamayo tuviera esa posibilidad. (Castro)

Not once in the long speech is López Falcón mentioned. In contrast to Tamayo Méndez, and in addition to being White (whatever that means in the Cuban imagination), he was the son of a middle-class family. After the Revolution, his father worked for the ministry of the food industry, and his mother for the ministry of transport. Tamayo Méndez's transformation into a cosmonaut was thus presented as 
another of the Revolution's successes, an overcoming of social inequality. Although Tamayo Méndez did not lack the merits to become a cosmonaut, his selection, and Fidel Castro's emphasis on his status as a Black boy from a low-income family who had managed to reach outer space thanks to the Revolution, still provides an interesting nuance to think about why he was the one selected to fly in the joint mission. One might also speculate that another reason for choosing Tamayo Méndez was his familial ties with Harry Antonio Villegas Tamayo, who fought beside Ernesto Guevara in the Sierra Maestra before 1959, in the Congo in 1965, and then in Bolivia in 1967. (v)

The racial issue also had an impact on the geopolitical relationship between Cuba and the Soviet Union: between 1975 and 1990, when Soviet-Cuban relations reached their peak, about 300,000 Cuban troops were dispatched to Africa to advance Soviet global interests. This deployment was a huge boost to Soviet aims because Cuban soldiers of African descent could pose as local African fighters and avoid calling attention to Soviet-Cuban intervention in the African wars. It is important to remember that at the Second Congress of the Communist International (Comintern) in July 1920, Lenin had argued that "all Communist parties must give active support to the revolutionary movements of liberation of the nationalist bourgeoisies of the colonies" (Matusevich 59). Years later and in another context, it was almost impossible for the Soviet Union to intervene in the African wars. But Cuba, which was leading the Non-Aligned Movement at the time, was in the best position to become the extension of the Soviet Union's fighting arm in Africa. (vi)

As part of their self-portrayal as a "racism-free paradise," during the first half of the twentieth century the Soviet Union welcomed many Black people - both famous personalities and regular citizens- especially from the United States. Most of the time, these people were received and given a special status: after all, most of them were Americans who were supposed to experience firsthand the moral "superiority" of socialism. Among the Black figures who traveled to the USSR was the Jamaican writer Claude McKay (in 1922). US poet Langston Hughes and US actors Paul Robeson and Lloyd Patterson were part of a group of twenty-one Black intellectuals and artists who moved to the Soviet Union in 1932 to take part in the film Black and White, commissioned by the Communist International. The project never materialized, but some of the artists decided to stay. In the years that followed, thousands of students from Africa also traveled to the Soviet Union.

One of the most famous and best-loved Soviet movies from the 1930s, Circus, a musical comedy directed by Grigori Aleksandrov, offers a racial counterpoint between the United States and the Soviet Union, presenting the latter as a "racism-free paradise": it is the story of a biracial family -a White American actress with a Black child - who visit the Soviet Union and find sympathy and friendship there. After the movie, the child became a "symbol of Soviet internationalism and its struggle against racism" (Razor, vii).

But there were other portrayals of African people, not always with a positive effect. As Raquel Greene says:

In their depictions of Africa and people of African origin, Soviet children's writers frequently reinforced stereotypes that may ultimately have had, however unintentionally, a negative impact on how Soviets perceived people of African origin. One example from Soviet popular culture would be the song "Chunga Changa." Made popular by the animated film Katerok [Boat] (1970), "Chunga Changa" presents Africa as a land of exotic animals and carefree, banana-eating natives whose primitivism is idealized. But this presumably positive view of Africa has a clear, patronizing subtext. ("Constructions of Africa in Early Soviet Children's Literature”)

\section{CUBANS IN THE SOVIET UNION}

After the Revolution of 1959, a large number of Cubans went to the former Soviet Union to complete their professional education and training. It is estimated that there were at least 300,000 in the thirty years that the exchange between the two countries lasted; the actual figure is unknown. Many of these students developed romantic relationships with people from the Soviet Union, mainly Cuban men and Soviet women. Several of those couples, moreover, were interracial. In a number of cases, these couples lived for some time in Cuba.

In 2006, Cuban filmmakers Gustavo Pérez and Oneyda González made a documentary entitled Todas iban a ser reinas (They Were All Going to Be Queens), in which they interviewed several women of Soviet origin from various former Soviet republics. The only thing the women had in common was having followed their husbands to Cuba. They talked about how their lives were transformed once they arrived on the island. One statement is quite telling in terms of racial interaction and perception. Irina Pelaeza, from Latvia, described her husband thus:

un compañero exótico, con espendrum, con su piel bronceada (porque estábamos en julio), con la sonrisa espléndida esa de los cubanos, que me mató, me mató, me deslumbró. Me llegó acá y me mató para el resto de mi vida. Porque sonreír así solamente podían los cubanos. (0०:०2:15-00:02:33) (viii)

Despite the admiration and love that Irina's words transmit, they can also be read as an example of the exoticization with which Cubans, especially Blacks, were viewed in 
the Soviet Union at the time. The Ukrainian film critic Zoia Barash, in an interview with Elizabeth Mirabal Llorens, said:

Pienso que los matrimonios mixtos entre soviéticas y cubanos tuvieron mucha importancia para el ambiente del país. Centenares de soviéticas que se casaron con mulatos y negros cubanos disolvieron un poco y a nivel personal cierto ambiente de prejuicios raciales. (Mirabal Llorens 51)

Barash, who passed away on October 26, 2014, lived in Cuba for more than 50 years, although she first arrived there to work as a translator, and later formed a family and stayed on the island for the rest of her life. (ix)

On this subject of mixed marriages between Soviets and Cubans, the statement made by Cuban writer José Miguel Sánchez (Yoss) is also noteworthy. Yoss participated, together with Zoia Barash and other intellectuals, in a colloquium in Havana on May 28, 2009, organized by the magazine Temas, to discuss culture, race, and identity in the context of Russian cultural traces in Cuba. In that forum, Yoss said:

Independientemente de cualquier acercamiento estatal u oficial que se preconizara, que se basara en cuestiones ideológicas, también existió un acerca miento personal mediado por el exotismo. Piensen en lo que era para un cubano, en 1959, una rubia de ojos azules; era un personaje de película yanqui; de pronto llegan las primeras rusas rubias de ojos azules que no solo no nos despreciaban, sino que les mostraron a los blancos cubanos que el negro también podía ser bonito y atractivo. Hubo y hay muchos estereotipos, es cierto . .. pero, independientemente de todas estas cuestiones, había un extraordinario interés hacia las diferencias. (58)

Although the exact number of how many interracial couples were formed between Cubans and Soviets is not known, the women interviewed in Todas iban a ser reinas attest to the existence of this phenomenon and are the tip of the iceberg of a much larger process in which Soviet love, admiration, and fascination for Cubans, but in particular for Black and mulato Cubans, became part of both countries' social reality.

On the other hand, it is interesting to read the recollections of former Chairman of the Presidium of the Supreme Soviet, Anastas Mikoyan,when he talks about the first Cubans who went to the Soviet Union to learn a trade. He does not mention a generic Cuban, but specifies a hypothetical Juan, a Black Cuban who formed sentimental ties with a Soviet family in which he was welcomed, loved, and taken care of:
No dudamos de que después de tantos años, en algún poblado cubano, recuerde hoy el negro Juan, padre ya desde hace tiempo de una numerosa familia, a la "tía Katia," que trabajaba de conserje en el centro del pueblo de cosacos del Kubán, e invitaba a su casa los domingos a estos muchachos de la lejana Cuba ("porque sus madres están tan lejos ...”) para quererlos con su cálido corazón de madre que había perdido para siempre en la guerra a sus cuatro hijos ... Y esto fue también un "hilo" de la firme amistad que estableció entre nosotros una base indestructible de relaciones mutuas. (Nabel Pérez 254) (x)

However, the Cubans were not the first or the only Blacks to arrive in the former USSR, as already mentioned. It is estimated that about sixty thousand students from Africa went to the Soviet Union between 1949 and 1991. Many of them also formed interracial couples. (xi)

In his article "An Exotic Subversive: Africa, Africans, and the Soviet Everyday," Maxim Matusevich explores the special place that Africans played in the formulation of an early Soviet identity:

Having assumed power in 1917 and established the first socialist state in history, the Bolsheviks quickly positioned themselves as the natural allies of those oppressed by international capitalism ... [A]cross the capitalist world, non-white people (whether in the colonies or in the diaspora) consistently represented the most exploited and the most discriminated-against segments of the population. For the Bolsheviks to embrace the peoples of colour wherever they might be was not a leap of faith but the logical extension of their most intrinsic beliefs. (59)

This cycle that started with an idea in 1917 came to fruition first with the arrival of African students to the Soviet Union, and then with the close relationship between Soviets and Cubans that also included Cuba's military intervention in Africa.

\section{SOVIET POETRY AND CUBAN RACE}

When Vladimir Mayakovski was in Havana on July 4, 1925, he must have felt a sense of strangeness around Black Cubans. What he saw shocked him enough to inspire his poem "Blek end uait" (so titled by Mayakovski, using the Cyrillic alphabet -Блек энд уайт- and then translated into English by Langston Hughes, with the help of Lidiia Filatova, as "Black and White"). In this poem he narrates Black exploitation at the hands of White people. It was published in Russian and Spanish (translated by Angel Augier) in the bilingual anthology prepared by Augier, Nina Bulgakova, Eliseo Diego, and Alexei Smolnikov, titled 
Москва-Гавана. Гавана-Москва. Стихи советских и кубинских поэтов / Moscú-La Habana, La Habana-Moscú. Poetas cubanos y soviéticos in 1977:

\author{
Pero grabó \\ una cosa en su memoria, \\ sólida, \\ cual es la estatua \\ de Maceo: \\ “Tócale al blanco \\ la piña madura, \\ y la podrida \\ solo alcanza el negro. \\ El trabajo más blanco \\ es para el blanco, \\ y el trabajo más negro- \\ para el negro... \\ Si el azúcar \\ blanco blanco \\ ¿por qué \\ tiene que hacerla \\ el negro negro? (Augier 106-10)(xii)
}

It was not, however, the only Afro-Cuban poem by Mayakovski. In "Syphilis" (“Сифилис," 1926), he describes a Black man who is quarantined in Havana's harbor, forced to wait until "a wealthy white American from first-class, Swift, the syphilitic 'pig king,' disembarks" (Lee 70).

Mayakovski's fixation on Black people is related to a Soviet identity in which the primary ideological goal was to liberate exploited communities throughout the world, as stated during the Second Congress of the Communist International. Another of Mayakovski's poems ("To Our Youth,” 1927, “Нашему юношеству,” originally in Russian) reads:

If I were an elderly negro
I would learn Russian

without being despondent or lazy

just because Lenin spoke it. (Mayakovski 6-9)

But even before Mayakovski, Russian travelers who had visited Cuba were impressed by the island's mulatez and natural beauty. At the beginning of 1850 , poet and translator Aleksandr Gavrilovich Rotchev (1807-73) traveled to the Americas as part of his work with the Russian-American Company.In Cuba, he visited Havana and Matanzas. Rotchev describes what he saw on the streets of these cities: "Mire a esa criolla: -iqué pierna tan pequeña, tan esbelta! Mire a una negra de alguna casa rica: está vestida espléndidamente. Mire a una mulata: ella sabe que no asusta el color negro de su piel y canturrea: 'Aunque soy morena, / no soy de olvidar."' (Nabel Pérez 14) (xiii)

It was not only the exotic (to Russian eyes) Blackness of the Cuban people that captivated the admiration of Russian travelers, but also their bravery. During the nineteenth century there was substantial commercial trade between Cuba and Russia, and Russians were concerned about slavery on the island. Publications such as Nedelya (Week), Delo (Business), and Budilnik (Alarm clock) echoed such concerns. At the end of that century, three young Russian men, Pyotr Streltsov, Yevstafy Konstantinovich, and Nikolai Melentyev, returned to their motherland after taking part in Cuba's second independence war (1895-98) against the Spanish army, under the command of Antonio Maceo. One of them, Streltsov, published an article titled "Two Months in the Island of Cuba" in the journal Véstnik Evropi (Bulletin of Europe) in which he described his experience fighting under Maceo, whom he called "the second Spartacus." (xiv)

After the Revolution in 1959, the government aligned itself with the Soviet socialist bloc in 1961, and the exchange between the two countries intensified exponentially. Some of this growth was evident in the constant trips that poets made from one nation to the other to "discover" their shared realities, and then to communicate to their compatriots what they had discovered. (xv)

As part of the intensification in the relationship between the two countries, many Cuban artists visited the former Soviet Union, where they were well received. Perhaps the best-known Cuban writer in the Soviet Union was Nicolás Guillén, who had been familiar to the Soviets well before 1959. Of Guillén's literary work, Ilyá Ehrenburg, one of Guillén's foremost translators into the Russian language, said in his 1966 book Gentes, años, vida:

Sus poemas son extraordinariamente musicales. Están relacionados con las canciones de los negros y mulatos cubanos. Él los lee muy bien; puede tocar una 
melodía golpeando con los dedos sus grandes y brillantes dientes blancos (Nabel Pérez 155)

According to Ehrenburg, Guillén was admired not only because of the quality of his poetry but also because his poems reflected mulata Cuba.

In addition to Guillén, other artists who represented Cuban culture's African roots were invited to present their works in the Soviet Union. It seems that for the Soviet people, Blackness and mulatez were synonyms of Cubanness. This phenomenon helps explain the success of many Cuban artists invited to present in the Soviet Union, such as the painters Wifredo Lam, whose first exhibit was in 1946; Manuel Mendive, whose primitivist paintings were part of the exhibition of Cuban art in Moscow in 1981; and René Portocarrero, among many others.

A very well-known poet in Cuba and Latin America, and one of the most prolific translators of Cuban poetry into Russian, Pavel Grushko, also had a similar vision of a mulata Cuba. In a poem dedicated to Portocarrero, "René Portocarrero y su ciudad” (“Рене Портокарреро -город и человек," originally in Russian, translated by Eliseo Diego), the poetic voice talks of a mulata city:

Mi ciudad vigilante,

mi maestra de vida, (xvi)

isi fue fácil quererte, mi mulata briosa! (Augier 178)

Mayakovski's "Black and White" was the inspiration, many years after its publication, for another Soviet poet, Nicolai Starshinov who in his poem "Esta desgracia, este dolor palpable” (“Эту боль, это горе,” originally in Russian, translated by David Chericián) refers to Mayakovski's poem but clarifies that Cuba was already experiencing a brilliant day, and white teeth were shining amid the black beards.

Desde entonces vivían en mi recuerdo

la ira del poeta y el dolor,

el rey de ultramar, gordo como un cerdo,

pegando al negro Willy en su color.

...

He aquí que en Cuba el alba ya despunta, ¿no escuchas como cantan los cubanos? Brillan los blancos dientes enmarcados en las barbas de sólida negrura ... (Augier 156-157)

Other Soviet artists and intellectuals were interested as well in the African roots of Cuban culture. For instance, Soviet Armenian musician Yuri Kazarián, while visiting Cuba in 1988, declared, "Traté de comprender el alma del arte-afrocubano, su ritmo" (Nabel Pérez 463).

Other poets were more explicit about their fascination with the issue of race in Cuba. For instance, Rasul Gamzatov, in his poem "La mulata," ("Мулатка," originally in Russian, translated by David Chericián) focuses the poetic emotion on the skin color of the woman he is contemplating:

Otra vez, inmadura una mitad

la luna apareció sobre la isla,

y como un solitario barco blanco

por el cielo callada se desliza.

Crujía la noche como seda negra,

y su rostro africano entonces vi

en Santiago, de pronto, sobre piedras

amarillas alzarse frente a mí.

Un riachuelo arabescos enlazaba

no lejos, respirando en su rumor

libertad, parecía la batuta

de un invisible director.

Dos mulatas cantaban, en las frases

de su canción chispeaban brasas puras,

de los labios calientes que llameaban

apenas se veían las comisuras.

Eran esas palabras como enigmas,

pero para mi oído nada más.

Ay, mulatas, ¿de dónde las sacaron?

¿De quién las aprendieron a cantar? 
¿Quizás, audaz y trémula,

junto al anillo del Caribe acuático,

así la madre negra les cantaba

sobre el padre de rostro blanco?

¿O quizá en la alta mar el padre negro

bajo la luna,

la canción cantaba

sobre aquella mujer de blanco rostro

que era su esposa amada?

Del padre y de la madre son los sones,

son los rasgos del padre y de la madre

que abrieron su camino a ser las reinas

de la belleza de los carnavales.

Oh Cuba, Cuba, mulata orgullosa,

enloquecí por ti, por tu canción,

eres la reina, eres un soldado

y eres tú misma la revolución.

Yo también hace tiempo que a mi vida

me acostumbré a considerar mulata,

cuya madre alza siempre la faz negra

y tiene el padre siempre la tez blanca.

Y también es mulata mi canción (Augier 113-14)

We have transcribed the poem at length because it epitomizes a complicated poetic Soviet fascination with race in Cuba. The poetic voice is evidently mesmerized by the black color of the woman's skin described and by the fire that emanates from her songs. At the end of the poem, there is a fundamental semantic twist: whereas the admiration is initially focused on two singing Black women, in the end there is only one woman, a mulata, the daughter of a Black mother and a White father. Although it is not mentioned directly, an obvious reference to slavery can be identified: the White man, master; the Black woman, enslaved. And that mulata woman becomes a soldier in the Cuban Revolution. This abrupt break at the semantic level could be related to the Soviets' complex dual fascination with Cuba: on the one hand, the Black or mulata woman served as the repository of a sensual and erotic meaning, in keeping with the way the Cuban woman has so often been presented, especially the Black or mulata - as a sexual object. On the other hand, the Revolution symbolized hope and the possibility of expanding the socialist legacy to other parts of the world, as well as a revitalization of a stagnant and outdated Soviet socialism, led at that time by a nomenklatura composed mainly of narrow-minded elderly men. The process of transforming idealized women as objects of desire and fascination (at the beginning of the poem) into admired figures with their own agency is ultimately imperfect and speaks, perhaps, to a Soviet inability to understand Cuban culture and identity. Nevertheless, the personification of the Revolution and its depiction as a mulata woman is reinforced by the title of the poem, which refers only to a single mulata, and not to two, the singers at the beginning of the poetic composition. Gamzatov's poem seems anachronistic, formally linked much more closely to the Black Poetry of the early twentieth century in Cuba than to the politically committed poetry of the Sixties.

Alexei Smolnikov, in his poem "Zafra," ("Cacppa," originally in Russian, translated by David Chericián) is also mesmerized both by Cuba's multichromatic identity and by the Revolution:

Cuba, dura y salada es tu azúcar famosa,

en las mejillas ásperas negro es tu sudor.

Pero es dentiblanca tu sonrisa radiosa

y a conciencia se hace tu constante labor. (Augier 154-55)

Meanwhile, Dmitri Kovaliov, in his poem "Eco” (“Эxo," in Russian, also translated by David Chericián), alludes to the relationship between Cuba and Africa:

El eco de nuestro Aurora Báltico por todo el mundova.

iSalud, África! iSalud,

lejana Cuba, salud!

¡Cuán cercano vuestro ímpetu profundo! (Augier 125) 
One of the most emblematic Soviet poets of all time, Yevgeny Yevtushenko, spent long periods in Cuba and even devoted an entire section of one of his poetry collections to his impressions of the island. In the twenty-one poems in the second part of Ternura. Nuevos versos (Нежность. Новые стихи, 1962), Yevtushenko is fascinated not so much with racial issues but primarily with Fidel Castro. Although the poet rarely wrote about women and romantic love, there are some instances in this part of the book in which he is seduced by the multichromatic hues of Cuban reality. For example, he compares the Cuban Revolution to a mulata woman, almost in the same way that Gamzatov did so at the end of his poem "La mulata." (xvii)

More interesting in this regard is Yevtushenko's work in the movie I Am Cuba. Allegorically speaking, in the film Cuba is presented as a mulata woman who is raped and abused by capitalism. One of the most allegorical characters, María, needs to be saved; in this sense, the film follows the same logic consistently presented since 1920: the Soviet Union was obliged to protect and rescue exploited people around the world, denying them or minimizing their own capacity for agency. María loves René, a fruit vendor who helps distribute clandestine pamphlets to students, but she is forced to be a prostitute at night, named Betty, and to renounce her Cuban lover. The end of the film portraying the triumph of the rebels who were fighting against Fulgencio Batista's dictatorship, suggests that María will be able to end her double and precarious life. In this sense, the defeat of the capitalist system, as presented in the movie, seems to vindicate her:

La narrativa cinematográfica del filme busca construir una metáfora de la isla y de su historia, según la cual Cuba y la Revolución serían equivalentes. O dicho de otro modo: el único destino posible para la isla era la Revolución, pero no cualquier revolución, sino esa que tuvo lugar. El filme se convirtió así en una producción simbólica que habría servido a su director y realizadores para satisfacer su necesidad de darle forma al imaginario soviético sobre la Revolución Cubana y justificar, en cierto modo, la fascinación que en los primeros años después de la llegada de las barbudos al poder sentía la cúpula gobernante del politburó soviético hacia aquellos jóvenes que desafiaban al imperio norteamericano a pocas millas de sus costas. (Puñales-Alpízar 483)

In this sense, there is a striking similarity between the idea of presenting Cuba and the Revolution as one and the same - as has always been the government's position- seen in the overlapping of a mulata woman and the Revolution, and the idea portrayed by Yevtushenko in one of his poems, which presents the Revolution as a woman to be loved. However, the poet does not focus on any particular trait of this woman other than her bravery.
Given his popularity, Yevtushenko had become a sort of cultural and ideological Soviet ambassador, while being perceived as a "soft dissident" among many in the Soviet Political Bureau of the Central Committee of the Communist Party of the Soviet Union (politburo). In 1963, for instance, Yevtushenko was invited by the poet and Senegalese president, Léopold Sédar Senghor, to the first Festival of Negro Arts. Senghor, who had his differences with Soviet socialism, thought that by making such a gesture, he would defy the Soviet regime, since Yevtushenko was invited as a Russian poet, not as an official representative of the Soviet government. In Dakar, however, "Evtushenko publicly defended his country's ideology and international policies" (Katsakioris 152). Yevtushenko was fascinated with Africa at a variety of levels: (xx)

On the margins of the official exchanges Africa became for Evtushenko a source of poetic inspiration, a land of mysterious beauty, exotic and strange, yet akin to his own mysterious country. As one scholar suggests, Evtushenko's verses lauding African freedom and the empathy of the Russian taiga for the African savannah were hardly empty of political meaning. Written in 1962 among expectations and struggle for a freer post-Stalinist Soviet country, they hid the message of liberalization within an exaltation of African liberation. His ideologically ambiguous tribute to African freedom bore no resemblance to the typical representations of Third World people's struggle in Soviet public discourse. (152)

Although Yevtushenko did not directly address Black or mulata Cuba, it can be stated that his fascination with Africa had not only aesthetic reasons but was also related to the subjectivity developed since the 1920 Second Congress of the Communist International regarding the Soviet Union's ideological commitment to liberating exploited and marginalized people across the rest of the world.

\section{CONCLUSION}

When Arnaldo Tamayo Méndez left Earth's orbit, he became the first person of African descent to enter outer space. Not to mention the first Cuban, the first citizen from Latin America, and the first from a Third World country. Moreover, he became the visible face of an ideological apparatus eager to show off the advantage enjoyed by the socialist system in the space race. In that sense, Tamayo became a multilayered signifier who fulfilled several quotas at once, and just as important as those quotas, he was a lowborn boy from a country located just 90 miles from the United States coast.

Besides the geopolitical import, at the suprapolitical level, of his being chosen to be sent into space, by the time he traveled with Romanenko aboard Soyuz 38 in 1980, the 
Soviet people had been in love with Cuba for two decades. While part of that love was manifested in the politically committed Soviet poetry from those decades, it was also evident in the Soviet fascination with the Cuban people and its mulata status.

In the Soviet imaginary, the Cuban mulato represented not only an exotic and different other but also the realization of another socialism, one possible in other conditions and other coordinates, (almost) far from Soviet reach. In general terms, Cubans fulfilled a diversified aspirational fantasy of Soviet identity concerning Black and exploited people, Latin America, the United States, and the triumph of the socialist ideology in other parts of the world. The Soviet fascination with, commitment to, and admiration for people of color had the added bonus that, in this case, Cubans were comrades from a socialist island right next door to the USSR's greatest global antagonist. 


\section{WORKS CITED}

Augier, Ángel, et al., editors. Москва-Гавана. ГаванаМосква. Стихи советских и кубинских поэтов / Moscú-La Habana, La Habana-Moscú. Poetas cubanos y soviéticos. Moscow: Progreso, 1977.

Burgess, Colin, and Bert Vis: "The Cuban Salyut Mission.” Interkosmos: The Eastern Bloc's Early Space Program. Springer-Praxis, 2016, pp. 127-42.

Castro, Fidel. "Discurso del 15 de octubre de 1980, por vuelo soviético-cubano al cosmos.” Cubamilitar.org. 18 Jan. 2014, http://www.cubamilitar.org/wiki/Fidel_Castro,_discurso_del_15_de_octubre_de_1980,_por_vuelo_sovietico-cubano_al_cosmos. Accessed 26 July 2020.

Duggan, Kevin. “Astronaut from Fort Collins Already Has 'the right stuff' ahead of International Space Station Mission." Coloradoan. 18 May 2018, https:/www.coloradoan.com/story/news/2018/05/18/astronaut-fort-collins-international-space-station-star/618989002/. Accessed 25 May 2020.

Greene, Raquel G. "Constructions of Africa in Early Soviet Children's Literature.” Black Perspectives. African American Intellectual History Society, 31 Oct. 2017, https:// www.aaihs.org/constructions-of-africa-in-early-soviet-childrens-literature/. Accessed 15 May 2020.

Katsakioris, Constantin. "The Soviet-South Encounter: Tensions and Friendship with Afro-Asian Partners, 1945-1965." Cold War Crossings: International Travel and Exchange across the Soviet Bloc, 1940s-1960s, edited by Patryk Babiracki and Kenyon Zimmer, Texas A\&M University Press, 2014, pp. 134-65.

Lee, Steven S. The Ethnic Avant-Garde: Minority Cultures and World Revolution. Columbia University Press, 2015 .

Matusevich, Maxim. "An Exotic Subversive: Africa, Africans and the Soviet Union Everyday.” Race and Class, vol. 49, no. 4, 2008, pp. 57-81.

Mayakovski, Vladimir. "Nashemu yunoshestvu." NL, no. 2, 1927, p. 26.

Mirabal Llorens, Elizabeth. "Decir toda la verdad. Entrevista con Zoia Barash.” Revista Revolución y Cultura no. 1, 2010, pp. 42-51.

Nabel Pérez, Blas. Cuba-URSS. Crónica. Moscú/La Habana: Editorial Progreso, 1990.

Puñales-Alpízar, Damaris. "Soy Cuba, Océano y Lisanka: De lo alegórico a lo cotidiano. Transformaciones en las coproducciones cubano-soviético-rusas." Revista Iberoamericana, vol. 79, no. 243, 2013, pp. 479-500.

Razor, Sasha. “The Only One Left: A Conversation with James Lloydovich Patterson about Grigori Aleksandrov's Circus.” Los Angeles Review of Books, 7 July 2020, https:// lareviewofbooks.org/article/the-only-one-left-a-conversation-with-james-lloydovich-patterson-about-grigori-aleksandrovs-circus/. Accessed 19 October 2020.

Sánchez, José Miguel (Yoss). "Huellas culturales rusas y de Europa del Este en Cuba.” Panel discussion. 28 May 2009, Centro Cultural Cinematográfico ICAIC, Havana, Cuba. http://www.temas.cult.cu/debates/libro\%20 4/050-069\%20rusos.pdf?fbclid=IwAR3F_PWVt6pu7Qb2WPCT4-XSU2uJTCo2rb2jJaoIuYPJIUg9_n_hUw3CcFg. Accessed 12 Jan. 2018 (no longer available online).

Saney, Isaac. "African Stalingrad: The Cuban Revolution, Internationalism, and the End of Apartheid." Latin American Perspectives, vol. 33, no. 5, 2006, pp. 81-117.

Todas iban a ser reinas. Directed by Gustavo Pérez Fernández, written by Oneyda González. Televisión Camagüey Producciones, 2006. $55 \mathrm{~min}$.

"Vuelo conjunto URSS-Cuba." Bohemia, 26 Sept. 1980, pp. 35-66.

Yegorov, Oleg. "How the USSR Fell in Love with Africa." Russia Beyond the Headlines. Russia Today, 6 Nov. 2019, https://www.rbth.com/history/331238-ussr-africa-relations-friendship. Accessed 5 Nov. 2020.

Yevtushenko, Yevgeny. Nezhnost; Novye stikhi. Москва: Sovetskiı Pisatel, 1962. 